\title{
Serine/Threonine-Protein Phosphatase 2A 56 kDa Regulatory Subunit Gamma Isoform
}

National Cancer Institute

\section{Source}

National Cancer Institute. Serine/Threonine-Protein Phosphatase 2A 56 kDa Regulatory

Subunit Gamma Isoform. NCI Thesaurus. Code C34089.

Serine/threonine-protein phosphatase 2A $56 \mathrm{kDa}$ regulatory subunit gamma isoform (524 aa, $61 \mathrm{kDa}$ ) is encoded by the human PPP2R5C gene. This protein may play a role in the regulation of protein phosphatase $2 \mathrm{~A}$ localization. 